УДК 631.816:631.559.2

DOI https://doi.org/10.32848/agrar.innov.2021.8.6

\title{
ВПЛИВ СИСТЕМИ ЖИВЛЕННЯ НА УРОЖАЙНІСТЬ ТА ЯКІСТЬ ЗЕРНА ПШЕНИЦІ ОЗИМОÏ
}

\author{
КЛІПАКОВА Ю.О. - кандидат сільськогосподарських наук \\ http://orcid.org/0000-0002-7054-9707 \\ Таврійський державний агротехнологічний університет імені Дмитра Моторного \\ БІлОУсОВА 3.В. - кандидат сільськогосподарських наук, доцент \\ http://orcid.org/0000-0001-9687-7920 \\ Таврійський державний агротехнологічний університет імені Дмитра Моторного \\ КЕНЄВА В.А. - аспірант \\ http://orcid.org/0000-0002-4890-651X \\ Таврійський державний агротехнологічний університет імені Дмитра Моторного \\ КОРОТКА І.О. - кандидат сільськогосподарських наук \\ http://orcid.org/0000-0002-5991-0186 \\ Таврійський державний агротехнологічний університет імені Дмитра Моторного
}

Постановка проблеми. Сучасна технологія вирощування пшениці озимої спрямована на максимально продуктивну відповідь рослин під час застосування засобів інтенсифікації виробництва, які нині використовуються у сільському господарстві України. Розкрити цей потенціал можливо за рахунок адаптації рослин до впливу біотичних та антропогенних чинників у період вегетації культури. Прогнозувати та корегувати величину врожаю, а в подальшому і якість отриманого зерна пшениці озимої, можна за рахунок природної родючості ґрунтів, яка на півдні України забезпечує врожайність у середньому до 4,0 т/га [1]. Внесення добрив за технологією вирощування у разі поєднання з іншими фракторами дає можливість підвищити врожай на 35-50\% і зберегти родючість ґрунту [2; 3].

Аналіз останніх досліджень і публікацій. У своїх дослідженнях А.О. Литовченко зі співавторами [4] зазначає, що внесення мінеральних добрив у декілька строків: $\mathrm{N}_{30} \mathrm{P}_{30}-$ до сівби, $\mathrm{N}_{30}-$ рано навесні та $\mathrm{N}_{30}-$ на початку колосіння сприяє зростанню показників якості зерна, а саме вмісту клейковини - до 30,6\%, білку - до 13,0\%, натури - до 783 г/л. Доведено [5], що застосування азотних добрив у дозах 30 і 60 кг/га підвищують продуктивну кущистість рослин пшениці озимої від 2,4 до 3,3 шт./рослину. Застосування добрив у дозі $\mathrm{N}_{60-90} \mathrm{P}_{60}$ збільшує кількість колосків у колосі від 15,0 до 21,0 шт., а маса 1000 зерен коливається від 39,3 до 43,5 г, що дозволило сформувати врожай пшениці озимої у межах 4,56-6,32 т/га [6].

Г.М. Господаренко зі співавторами [7] зазначає, що істотні прирости вмісту білка і клейковини одержано під час внесення азотних добрив дозою $\mathrm{N}_{60}$ у фазу кущіння рослин та $\mathrm{N}_{60}$ - їх виходу у трубку. Водночас показник стабільності вмісту клейковини за роками вирощування мав тенденцію до зниження в разі збільшення дози добрив. Слід звернути увагу на те, що в сортів пшениці озимої існує генотипова специфріка поглинання елементів живлення, особливо фосфрору [8; 9], а високе накопичення азоту негативно позначається на споживанні калію [10], тому вивчення системи живлення рослин у нестабільних погодних умовах залишається актуальним.
Метою дослідження $€$ встановлення впливу строку і способу внесення добрив на формування кількісних та якісних показників урожаю пшениці озимої в умовах Південного Степу України.

Матеріали та методика досліджень. Польові дослідження проводилися впродовж 2018-2020 років у стаціонарному досліді кафедри рослинництва імені профресора В.В. Калитки в науково-навчальному центрі Таврійського державного агротехнологічного університету імені Дмитра Моторного, який знаходиться в с. Лазурне Мелітопольського району Запорізької області. Ґрунт дослідного поля - чорнозем південний із вмістом гумусу 3,2-3,5\%, легкогідролізованого азоту (за Корнфілдом) 80,0-94,6 мг/кг, рухомого фросфрору (за Мачигіним) 38-43 мг/кг та обмінного калію (за Мачигіним) 380-420 мг/кг ґрунту, $\mathrm{pH}_{\text {ксІ }}-6,8$. Повторність досліду чотириразова, площа дослідної ділянки становила $100 \mathrm{~m}^{2}$, облікової - $50 \mathrm{~m}^{2}$.

У дослідженні використовували сорт пшениці озимої Шестопалівка, попередником якої був чорний пар. Насіння висівали у третій декаді вересня-першій декаді жовтня в добре підготовлений ґрунт звичайним рядковим способом, глибина загортання становила 5-6 см, норма висіву - 5,5 млн. шт./га. Технологія вирощування була загальноприйнятою для зони вирощування, крім досліджуваних фракторів. Погодні умови упродовж весняно-літньої вегетації 2019 та 2020 років за кількістю опадів різнилися - 197,6 мм та 149,9 мм. Слід зазначити, що у березні були відмічені мінімальні середньомісячні температури $\left(-6,6^{\circ} \mathrm{C}\right)$. Аналогічно у квітні $\left(-5,4^{\circ} \mathrm{C}\right)$ 2020 року на фоні недостатньої кількості опадів ( 9,9 мм) відновлення весняної вегетації та розвиток рослин загалом суттєво затримувались.

Схема досліду передбачала підживлення азотними добривами у два строки: ранній (І декада лютого) та пізній (І декада березня), котрі проводили з використанням аміачної селітри за допомогою РУМ. На початку фрази виходу у трубку вносили у грунт монофосфат калію разом із фоновим внесенням карбаміду (5 кг/га). В якості контролю слугували варіанти без внесення фосфрорно-калійного добрива. Норма витрат робочого розчину становила 200 л/га. 
Закладку дослідів, експериментальні дослідження та облік урожаю виконували згідно із загальноприйнятими рекомендаціями [11]. Натуру зерна визначали 3 використанням пурки на 1000 мл згідно з ГОСТ 10840-64 [12], вміст білка в зерні - методом К'єльдаля (ГОСТ 10846-91) [13], кількість та якість клейковини - шляхом механічного відмивання на приладі У1-МОК-1М (ГОСТ 13586.1-68) [15], індекс деформації клейковини визначали на приладі ВДК-1. За отриманими показниками технологічної якості зерна згідно з ДСТУ 3768:2019 встановлювали відповідний клас зерна [15].

Дисперсійний та кореляційний аналізи результатів досліджень проводили за методикою Б.О. Доспехова з використанням програм MS Office 2010 та Agrostat New [16].

Результати досліджень. За результатами проведеного дослідження нами встановлено, що різні строки і способи внесення добрив $€$ ефективними технологічними прийомами, що суттєво впливають на формування елементів структури врожаю і врожайність пшениці озимої загалом. Час внесення добрив значно впливає на формування кількості продуктивних пагонів на рослині. Оптимальним вважають застосування азотних добрив наприкінці другого етапу органогенезу, коли відбувається закладання осей другого порядку. Згідно зі схемою досліду раннє підживлення аміачною селітрою припадало на період закінчення II етапу органогенезу рослин пшениці озимої, тоді як пізнє - на початок III етапу, що відповідним чином і позначилося на кількості утворених колосків. Зокрема, найнижча густота продуктивного стеблостою на рівні 392 шт./M² була відмічена на контрольному варіанті в умовах пізнього підживленням азотом. Водночас в умовах раннього застосування $\mathrm{N}_{40}$ відбулося збільшення цього показника до 540 шт./м², що на $27 \%$ більше (табл. 1).

Позакореневе підживлення посівів у фразу початку виходу у трубку перешкоджає відмиранню вже сформованих продуктивних стебел і позитивно впливає на індивідуальну продуктивність рослин. Зокрема, застосування монофосфату калію позакореневим способом сприяло зростанню густоти продуктивного стеблостою в умовах раннього підживлення - на $14,6 \%$ та пізнього на $6,9 \%$ порівняно з контрольними варіантами.
Раннє підживлення азотними добривами позитивно впливало на фрормування довжини колосу за рахунок формування дещо більшої кількості члеників колосового стрижня, що стало можливим унаслідок кращого формування площі фоотосинтезуючої поверхні рослин, яка на стадії розвитку ВВСН 31 в 1,5 рази перевищувала відповідні значення в умовах пізнього внесення азотного підживлення. Зокрема, довжина колосу за внесення азоту в I декаді лютого була на $6 \%$ більшою порівняно з варіантом його внесення в I декаді березня. Застосування позакореневого підживлення фоссрорно-калійними добривами несуттєво впливало на цей показник.

Більш раннє надходження азоту до рослини сприяло активнішому закладанню колоскових горбочків, що проявилося у збільшенні кількості колосків у колосі на 9,6\% порівняно з пізнім його внесенням. Позакореневе внесення монофосфрату калію сприяло подальшому збільшенню кількості колосків на $5 \%$ порівняно з контролем як за раннього, так і за пізнього внесення азотних добрив.

За рахунок формування більшої довжини колосу з підвищеною кількістю колосків у ньому раннє підживлення азотом забезпечувало зростання кількості зерен у колосі на $32 \%$ порівняно з пізнім його внесенням. Застосування монофросфату калію на фоні раннього підживлення азотними добривами суттєво не впливало на збільшення озерненості колосу. Водночас такий агрономічний прийом мав високу ефективність на фоні пізнього азотного підживлення, сприяючи зростанню цього показника на 17,5\% порівняно з контролем, що узгоджується з результатами інших досліджень [17-19].

Maca кожної окремої зернини i, як наслідок, 1000 насінин залежить від перебігу синтезу і транспортування запасних поживних речовин із вегетативних органів у репродуктивні. Згідно з отриманими результатами, в усіх варіантах застосування першого підживлення були створені сприятливі умови для проходження цього фізіологічного процесу, тому суттєвої різниці за масою 1000 насінин відмічено не було. Разом із тим за рахунок фрормування більшої кількості зерен у колосі відмічено незначне зниження цього показника у варіантах із позакореневим внесенням монофосфату калію.

Елементи структури врожаю та біологічна врожайність пшениці озимої залежно від досліджуваного фактору (середнє за 2019-2020 рр.)

\begin{tabular}{|c|c|c|c|c|c|c|c|c|}
\hline \multirow{2}{*}{$\begin{array}{c}\text { Фактор А } \\
\text { (перше } \\
\text { підживлення) }\end{array}$} & \multirow{2}{*}{$\begin{array}{c}\text { Фактор В } \\
\text { (позакореневе } \\
\text { підживлення) }\end{array}$} & \multirow{2}{*}{$\begin{array}{c}\text { Густота } \\
\text { продукт. } \\
\text { стеблостою, } \\
\text { шт./M² }\end{array}$} & \multirow{2}{*}{$\begin{array}{c}\text { Довжина } \\
\text { колоса, см }\end{array}$} & \multicolumn{2}{|c|}{$\begin{array}{c}\text { Кількість } \\
\text { у колосі, шт } \\
\end{array}$} & \multicolumn{2}{|c|}{ Maca, r } & \multirow{2}{*}{ 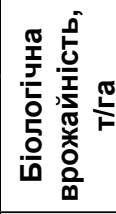 } \\
\hline & & & & колосків & зерен & $\begin{array}{c}\text { зерен } \\
\text { в колосі }\end{array}$ & $\begin{array}{c}1000 \\
\text { зерен }\end{array}$ & \\
\hline \multirow{2}{*}{ раннє } & контроль & 540 & 7,51 & 15,97 & 35,20 & 1,48 & 42,10 & 7,99 \\
\hline & монофосфрат калію & 619 & 7,78 & 16,83 & 35,80 & 1,39 & 38,80 & 8,60 \\
\hline \multirow{2}{*}{ пізнє } & контроль & 392 & 7,04 & 14,57 & 26,60 & 1,13 & 42,60 & 4,43 \\
\hline & монофосфрат калію & 419 & 7,24 & 15,29 & 31,27 & 1,27 & 40,76 & 5,32 \\
\hline \multirow{2}{*}{$\mathrm{HIP}_{05}$} & фрактору A & 38 & 0,24 & 0,98 & 2,21 & 0,07 & 2,33 & 0,43 \\
\hline & фактору В & 31 & 0,18 & 0,76 & 1,56 & 0,06 & 1,65 & 0,37 \\
\hline
\end{tabular}


Якість зерна пшениці озимої залежно від досліджуваного фактору (середнє за 2019-2020 рр.)

\begin{tabular}{|c|c|c|c|c|c|c|}
\hline $\begin{array}{c}\text { Фактор А } \\
\text { (перше } \\
\text { підживлення }\end{array}$ & $\begin{array}{c}\text { Фактор В } \\
\text { (позакореневе } \\
\text { підживлення) }\end{array}$ & $\begin{array}{l}\text { Натура, } \\
\text { г/л }\end{array}$ & $\begin{array}{c}\text { Вміст } \\
\text { білка, \% }\end{array}$ & $\begin{array}{c}\text { Вміст клейковини, } \\
\%\end{array}$ & $\begin{array}{c}\text { ІДК, } \\
\text { ум. од. }\end{array}$ & $\begin{array}{c}\text { Клас зерна } \\
\text { ДСТУ 3768:2019 }\end{array}$ \\
\hline \multirow{2}{*}{ раннє } & контроль & 776 & 13,7 & 25,1 & 81 & II \\
\hline & монофосфрат калію & 762 & 14,1 & 27,0 & 92 & II \\
\hline \multirow{2}{*}{ пізнє } & контроль & 771 & 11,3 & 22,7 & 80 & III \\
\hline & монофосфрат калію & 751 & 12,6 & 23,9 & 85 & II \\
\hline \multirow{2}{*}{$\mathrm{HIP}_{05}$} & фактору A & 6 & 0,7 & 1,2 & 5 & - \\
\hline & фактору B & 13 & 0,5 & 0,9 & 2 & - \\
\hline
\end{tabular}

Біологічна врожайність пшениці озимої обумовлена насамперед такими показниками, як густота продуктивного стеблостою і маса зерен з одного колосу. Як зазначалося вище, час і способи застосування підживлення суттєво впливали на вказані показники, що відповідним чином і позначилося на показнику біологічного врожаю рослин, який на контрольному варіанті за раннього внесення азоту був сформований на рівні 7,99 т/га, що в 1,8 рази перевищило відповідний варіант у разі пізнішого внесення азоту. Застосування монофоссрату калію для обох строків використання аміачної селітри у разі підживлення зумовило збільшення біологічної врожайності на 0,61-0,89 т/га, що свідчить про доцільність позакореневого застосування цього добрива.

За даними проведеного дослідження, строк азотного підживлення пшениці озимої у поєднанні з позакореневим внесенням монофосфрату калію по-різному впливав на фрормування якісних показників зерна (табл. 2).

Натура зерна залежить більшою мірою від сорту та умов вирощування у фазу наливу зерна, від середньодобової температури та умов зволоження, тому досліджувані агроприйоми суттєво не впливали на її величину.

Визначальними показниками оцінки якості зерна пшениці озимої $є$ вміст білка, кількість та якість клейковини [20]. За результатами дослідження, раннє підживлення азотом забезпечило більш активне поглинання рослинами азоту із грунту та його накопичення у вегетативних органах із подальшим активним відтоком до репродуктивних органів, що проявилось у збільшенні вмісту білка в зернівці на 21,3\%, кількості клейковини на 10,6\% порівняно з варіантом пізнього підживлення. Позакореневе внесення фосфорно-калійних добрив сприяло подальшій активізації цього процесу, проте по-різному впливало на накопичення білкових речовин залежно від фону першого підживлення. Зокрема, збільшення загальної білковості зерна на $11,5 \%$ було відмічено за використання монофросфату калію на фоні пізнього внесення азоту, тоді як на фоні його раннього внесення спостерігалося збільшення кількості клейковини на 7,6\% порівняно з контролем.

Якість клейковини, яка визначається показником ІДК, не залежала від досліджуваних агроприйомів, оскільки вирішальним фактором її формування $€$ вплив температури й вологості повітря у фразу воскової стиглості зерна.

Загалом згідно 3 ДСТУ 3768:2019 «Пшениця. Технічні умови» зерно пшениці озимої усіх дослідних варіантів відноситься до 2-3 класу якості продовольчого напрямку і може бути використане у борошномельній і хлібопекарській галузі та для експортування.

Висновки. Результати проведених досліджень свідчать про високу ефективність таких агрозаходів, як своєчасне внесення азотних добрив у дозі $\mathrm{N}_{40}$ за першого підживлення та застосування у баковій суміші для позакореневої обробки рослин пшениці озимої у стадію ВВСН 31 монофоосфату калію (1 л/га). За рахунок зростання окремих елементів структури врожаю внесення азоту в I декаді лютого разом із підживленням фоссфорно-калійними добривами забезпечило формування 8,6 т/га зерна 2 класу якості.

\section{СПИСОК ВИКОРИСТАНОЇ ЛІТЕРАТУРИ:}

1. Колесникова Н. Д., Вердиш М. В., Шукайло С. П. Обґрунтування фракторів впливу на урожайність сортів озимої м'якої пшениці в зоні південного степу України. Зрошуване землеробство. 2014. №(61). C. 80-84.

2. Господаренко Г. М., Черно О. Д. Урожайність пшениці озимої після різних попередників на фоні тривалого застосування добрив у сівозміні. Землеробство. 2015. Вип. 1. С. 28-31.

3. Аверчев О. В., Куліш В. Ю., Лавренко С. О. Урожайність сортів пшениці дворучки залежно від строку сівби та норм мінеральних добрив у незрошуваних умовах Південного Степу України. Таврійський науковий вісник. 2020. Вип. 115. С. 4-12.

4. Литовченко А. О., Глушко Т. В., Сидякіна О. В. Якість зерна сортів пшениці озимої залежно від фракторів та умов року вирощування на півдні Степу України. Вісник аграрної науки Причорномор'я. 2017. Вип. 3. С. 101-110.

5. Гирка А. Д. Вплив локального азотного підживлення на формування показників структури врожаю озимої пшениці. Вісник Полтавської державної аграрної академії. 2009. № 1. С. 13-16.

6. Вожегова Р. А., Мунтян Л. В. Вплив різних доз азотного добрива та норм висіву на елементи структури врожаю сортів пшениці озимої. Вісник аграрноі науки Причорномор'я. 2015. Вип. 3 (86). С. 107-115.

7. Господаренко Г. М., Черно О. Д., Любич В. В., Рябовол Я. С., Крижанівський В. Г. Урожайність та хлібопекарські властивості зерна пшениці озимої при різних дозах і строках застосування азотних добрив. Вісник Полтавської державної аграрної академії. 2020. № 3. С. 21-31.

8. Deng Y., Teng W., Tong Y-P., Chen X-P. Zou C-Q. Phosphorus Efficiency Mechanisms of Two Wheat 
Cultivars as Affected by a Range of Phosphorus Levels in the Field. Frontiers Plant Science. 2018. Vol. 9. Article 1614. P. 1-12.

9. Звонар А. М. Вплив погодних умов року та сортових особливостей на споживання азоту та формування якості зерна пшениці озимої. Вісник аграрної науки Причорномор'я. 2020. Вип. 3. С. 87-95.

10. Hamnér K., Weih M., Eriksson J., Kirchmann H. Influence of nitrogen supply on macro- and micronutrient accumulation during growth of winter wheat. Field Crops Research. 2017. Vol. 213. pp.118-129.

11. Єщенко В. О., Копитко П. Г., Опришко В. П., Костогриз П. В. Основи наукових досліджень в агрономії. Вінниця : ПП «ТД «Едельвейс і К»», 2014. $332 \mathrm{c}$.

12. ГОСТ 10840-64. Зерно. Методы определения натуры. [Дата введения 01.07.1965]. Москва, 1965. 4 с.

13. ГОСТ 10846-91. Зерно и продукты его переработки. Методы определения белка. [Дата введения 01.06.1993]. Москва, 1991. 6 с.

14. ГОСТ 13586.1-68. Зерно. Методы определения количества и качества клейковины в пшенице. [Дата введения 01.06.1968]. Москва, 1968. 5с.

15. ДСТУ 3768:2019. Пшениця. Технічні умови. [Чинний від 10.06.2019 р.]. Київ, 2019. 14 с.

16. Доспехов Б. А. Методика полевого опыта (с основами статистической обработки результатов исследования). Москва : Агропромиздат, 1985. 351 с.

17. Олійник К. М., Давидюк Г. В., Клименко І. І., Дем'янюк О. С. Вплив технологій вирощування пшениці озимої на морфоорізіологічні та агрохімічні аспекти фрормування врожаю. Агроекологічний журнал. 2020. № 4. С. 95-105.

18. Hanhur V. V., Kocherha A. A., Pypko O. S., Kabak Y. I., Len $\mathrm{O}$. I. The influence of mineral fertilizers on water consumption and productivity of winter wheat. Bulletin of Poltava State Agrarian Academy. 2020. № 3. pp. 54-60.

19. Мазуренко Б. О. Вплив азотного підживлення на формування елементів продуктивності тритикале-дворучки за пізніх осінніх строків сівби в умовах Правобережного Лісостепу. Миронівський вісник. 2018. № 7. C. 134-145.

20. Білоусова 3. В., Кліпакова Ю. О. Технологічні властивості зерна інтенсивних сортів пшениці озимої. Праці Таврійського державного агротехнологічного університету. 2019. Вип. 19. Т. 1. С. 262-269.

\section{REFERENCES:}

1. Kolesnykova, N. D., Verdysh, M. V., Shukailo, S. P. (2014). Obgruntuvannia faktoriv vplyvu na urozhainist sortiv ozymoi miakoi pshenytsi v zoni pivdennoho stepu Ukrainy [Substantiation of factors influencing the yield of winter soft wheat varieties in the southern steppe zone of Ukraine]. Zroshuvane zemlerobstvo - Irrigated Agriculture, 61, 80-84 [in Ukrainian].

2. Hospodarenko, H. M., Cherno, O. D. (2015). Urozhainist pshenytsi ozymoi pislia riznykh poperednykiv na foni tryvaloho zastosuvannia dobryv u sivozmini [The yield of winter wheat after different predecessors under long-term fertilization in crop rotation]. Zemlerobstvo Agriculture, 1, 28-31 [in Ukrainian].

3. Averchev, O. V., Kulish, V. Yu., Lavrenko, S. O. (2020). Urozhainist sortiv pshenytsi dvoruchky zalezhno vid stroku sivby ta norm mineralnykh dobryv $u$ nez- roshuvanykh umovakh Pivdennoho Stepu Ukrainy [Productivity of wheat (spring and winter compatible) varieties depending on sowing dates and mineral fertilizer rates under the irrigated conditions of the Southern Steppe of Ukraine]. Tavriiskyi naukovyi visnyk - Taurian Scientific Bulletin, 115, 4-12 [in Ukrainian].

4. Lytovchenko, A. O., Hlushko, T. V., Sydiakina, O. V. (2017). Yakist zerna sortiv pshenytsi ozymoi zalezhno vid faktoriv ta umov roku vyroshchuvannia na pivdni Stepu Ukrainy [Grain quality of winter wheat varieties depending on the factors and conditions of the year of cultivation in the south of Ukrainian Steppe]. Visnyk ahrarnoi nauky Prychornomoria - Ukrainian Black Sea region agrarian science, 3, 101-110 [in Ukrainian].

5. Hyrka, A. D. (2009). Vplyv lokalnoho azotnoho pidzhyvlennia na formuvannia pokaznykiv struktury vrozhaiu ozymoi pshenytsi [Influence of local nitrogen fertilization on the formation of indicators of winter wheat yield structure]. Visnyk Poltavskoi derzhavnoi ahrarnoi akademii - Bulletin of Poltava State Agrarian Academy, 1, 13-16 [in Ukrainian].

6. Vozhehova, R. A., Muntian, L. V. (2015). Vplyv riznykh doz azotnoho dobryva ta norm vysivu na elementy struktury vrozhaiu sortiv pshenytsi ozymoi [The infl uence of different doses of nitrogen fertilizers and seeding rates on the structure elements of harvest of winter wheat]. Visnyk ahrarnoi nauky Prychornomoria - Ukrainian Black Sea region agrarian science, 3 (86), 107-115 [in Ukrainian].

7. Hospodarenko, H. M., Cherno, O. D., Liubych, V. V., Riabovol, Ya. S., Kryzhanivskyi, V. H. (2020). Urozhainist ta khlibopekarski vlastyvosti zerna pshenytsi ozymoi pry riznykh dozakh i strokakh zastosuvannia azotnykh dobryv [Yield and baking properties of winter wheat grain at different doses and terms of nitrogen fertilizer application]. Visnyk Poltavskoi derzhavnoi ahrarnoi akademii - Bulletin of Poltava State Agrarian Academy, 3, 21-31 [in Ukrainian].

8. Deng, Y., Teng, W., Tong, Y-P., Chen, X-P. Zou, C-Q. (2018). Phosphorus Efficiency Mechanisms of Two Wheat Cultivars as Affected by a Range of Phosphorus Levels in the Field. Frontiers Plant Science, 9:1614, $1-12$.

9. Zvonar, A. M. (2020). Vplyv pohodnykh umov roku ta sortovykh osoblyvostei na spozhyvannia azotu ta formuvannia yakosti zerna pshenytsi ozymoi [Influence of weather conditions of the year and variety features on nitrogen consumption and formation of winter wheat grain quality]. Visnyk ahrarnoi nauky Prychornomoria - Ukrainian Black Sea region agrarian science, 3, 87-95 [in Ukrainian].

10. Hamnér, K., Weih, M., Eriksson, J., Kirchmann, H. (2017). Influence of nitrogen supply on macro- and micronutrient accumulation during growth of winter wheat. Field Crops Research, 213, 118-129 [in English].

11. Yeshchenko, V. O., Kopytko, P. H., Opryshko, V. P., Kostohryz, P. V. (2014). Osnovy naukovykh doslidzhen $\mathrm{v}$ ahronomii [Fundamentals of scientific research in agronomy]. - Vinnytsia: PP «TD «Edelveis i K»», $332 \mathrm{~s}$. [in Ukrainian].

12. HOST 10840-64. Zerno. Metodы opredelenyia naturb [Corn. Methods for determining nature.]. [Data vvedenyia 01.07.1965]. Moskva, 1965. 4 s. [in Russia]. 
13. HOST 10846-91. Zerno y produktы eho pererabotky. Metodu opredelenyia belka [Grain and products of its processing. Protein determination methods.]. [Data vvedenyia 01.06.1993]. Moskva, 1991. 6 s. [in Russia].

14. HOST 13586.1-68. Zerno. Metodb opredelenyia kolychestva y kachestva kleikovynы v pshenytse [Corn. Methods for determining the quantity and quality of gluten in wheat]. [Data vvedenyia 01.06.1968]. Moskva, 1968. 5s. [in Russia].

15. DSTU 3768:2019. Pshenytsia. Tekhnichni umovy [Wheat. Specifications]. [Chynnyi vid 10.06.2019 r.]. Kyiv, 2019. 14 s. [in Ukrainian].

16. Dospekhov, B.A. (1985). Metodyka polevoho opыta (s osnovamy statystycheskoi obrabotky rezultatov yssledovanyia) [Field experiment technique (with the basics of statistical processing of research results)] Moskva: Ahropromyzdat, 351 p. [in Russia].

17. Oliinyk, K. M., Davydiuk, H. V., Klymenko, I. I., Demianiuk, O. S. (2020). Vplyv tekhnolohii vyroshchuvannia pshenytsi ozymoi na morfofiziolohichni ta ahrokhimichni aspekty formuvannia vrozhaiu [Influence of winter wheat growing technologies on morphophysiological and agrochemical aspects of crop formation] Ahroekolohichnyi zhurnal - Agroekologikal Journal, 4, 95-105 [in Ukrainian].

18. Hanhur, V. V., Kocherha, A. A., Pypko, O. S., Kabak, Y. I., Len, O. I. (2020). The influence of mineral fertilizers on water consumption and productivity of winter wheat. Bulletin of Poltava State Agrarian Academy, 3, 54-60 [in Ukrainian].

19. Mazurenko, B. O. (2018). Vplyv azotnoho pidzhyvlennia na formuvannia elementiv produktyvnosti trytykaledvoruchky za piznikh osinnikh strokiv sivby $v$ umovakh Pravoberezhnoho Lisostepu [Influence of nitrogen fertilization on the formation of triticale-two-handed productivity elements in the late autumn sowing dates in the conditions of the Right-Bank Forest-Steppe]. Myronivskyi visnyk - Myronivka Bulletin, 7, 134-145 [in Ukrainian].

20. Bilousova, Z. V., Klipakova, Yu. O. (2019). Tekhnolohichni vlastyvosti zerna intensyvnykh sortiv pshenytsi ozymoi [Technological properties of grain of intensive varieties of winter wheat]. Pratsi Tavriiskoho derzhavnoho ahrotekhnolohichnoho universytetu Works Tavria State Agrotechnological University, 19(1), 262-269 [in Ukrainian].

Кліпакова Ю.О., Білоусова 3.В., Кенєва В.А. Коротка І.О. Вплив системи живлення на урожайність та якість зерна пшениці озимої

Мета дослідження - встановлення впливу строку і способу внесення добрив на формування кількісних та якісних показників врожаю пшениці озимої в умовах Південного Степу України.

Методи. Закладку дослідів та експериментальні дослідження проведено згідно із загальноприйнятими рекомендаціями 3 використанням загальнонаукових, спеціальних та математично-статистичних методів дослідження.

Результати. Час та способи застосування підживлень суттєво впливали на фоомування окремих елементів структури врожаю, що відповідним чином і позначилося на показнику біологічної урожайності рослин пшениці озимої, яка в контрольному варіанті за раннього внесення азоту була сформована на рівні 7,99 т/га, що в 1,8 рази перевищує відповідний варіант у разі більш пізнього внесення азоту. Застосування монофоссрату калію для обох строків використання аміачної селітри за підживлення позначилось у збільшенні біологічної врожайності на 0,61-0,89 т/га, що свідчить про доцільність позакореневого застосування цього добрива.

Раннє підживлення азотом сприяло збільшенню вмісту білка в зернівці на 21,3\%, кількості клейковини на 10,6\% порівняно з варіантом пізнього підживлення. Позакореневе внесення фосфорно-калійних добрив забезпечило збільшення загальної білковості зерна на $11,5 \%$ за використання монофоссрату калію на фоні пізнього внесення азоту, тоді як на фоні його раннього внесення спостерігалося збільшення кількості клейковини на $7,6 \%$ порівняно з контролем.

Зерно пшениці озимої усіх дослідних варіантів відноситься до 2-3 класу якості продовольчого напрямку і може бути використане у борошномельній і хлібопекарській галузі та для експортування.

Висновки. Результати проведених досліджень свідчать про високу ефрективність таких агрозаходів, як своєчасне внесення азотних добрив у дозі $\mathrm{N}_{40}$ за першого підживлення та застосування у баковій суміші для позакореневої обробки рослин пшениці озимої у стадію ВВСН 31 монофоосфату калію (1 л/га). За рахунок зростання окремих елементів структури врожаю, внесення азоту у I декаді лютого разом із підживленням фоосфорно-калійними добривами нами отримано 8,6 т/га зерна 2 класу якості.

Ключові слова: перше підживлення, позакореневе підживлення, монофосфат калію, структура врожаю, показники якості.

Klipakova Yu.O., Bilousova Z.V., Keneva V.A., Korotka I.O. Influence of the fertilization system on yield and grain quality of winter wheat

Aim of the research - to establish the influence of terms and methods of fertilizer application on the formation of quantitative and qualitative indices of winter wheat yield in the conditions of the Southern Steppe of Ukraine.

Methods. Experimental studies were carried out in accordance with generally accepted recommendations using general scientific, special and mathematical-statistical research methods.

Results. Terms and methods of fertilization had a significant impact on the formation of individual elements of the crop yield structure, which accordingly affected the value of biological yield of winter wheat plants, which in the control variant with early nitrogen application amounted to $7.99 \mathrm{t} / \mathrm{ha}$, which is 1.8 times higher than the corresponding variant with later nitrogen application. The use of potassium monophosphate for both terms of ammonium nitrate use in fertilization was reflected in the increase of biological yield by $0.61-0.89 \mathrm{t} / \mathrm{ha}$, which indicates the feasibility of foliar application the selected fertilizer.

Early fertilization with nitrogen increased the protein content in the grain by $21.3 \%$, and the amount of gluten by $10.6 \%$ compared to the variant of late fertilization. Foliar application of phosphorus-potassium fertilizers provided an increase in total grain protein by $11.5 \%$ with the use of potassium monophosphate on the background 
of late nitrogen application, while on the background of its early application there was an increase in gluten by $7.6 \%$ compared to control.

Winter wheat grain in all variants of the experiment belongs to 2-3 classes of food quality and can be used in the flour-milling and baking industry, as well as for export.

Conclusions. The results of the studies indicate the high efficiency of such agricultural measures as timely application of nitrogen fertilizers at a dose of $\mathrm{N}_{40}$ in the first fertilization and use of potassium monophosphate ( $1 / /$ ha) in the tank mixture for foliar treatment of winter wheat plants in stage $\mathrm{BBCH} 31$. Due to the increase of individual elements of the crop yield structure, nitrogen application in the tenday period of February in combination with phosphoruspotassium fertilization ensured the formation of $8.6 \mathrm{t} / \mathrm{ha}$ of grain of class 2 quality.

Key words: first fertilization, foliar fertilization, potassium monophosphate, yield structure, quality indicators. 